\title{
Studies on the Electrification of the Transport Sector in the Island of Crete, Greece
}

\author{
John Vourdoubas \\ Mediterranean Agronomic Institute of Chania, Chania, Greece \\ Email: vourdoubas@maich.gr
}

How to cite this paper: Vourdoubas, J. (2018) Studies on the Electrification of the Transport Sector in the Island of Crete, Greece. Open Journal of Energy Efficiency, 7, 19-32.

https://doi.org/10.4236/ojee.2018.71002

Received: February 6, 2018

Accepted: March 16, 2018

Published: March 19, 2018

Copyright $\odot 2018$ by author and Scientific Research Publishing Inc. This work is licensed under the Creative Commons Attribution International License (CC BY 4.0).

http://creativecommons.org/licenses/by/4.0/

(c) (i) Open Access

\begin{abstract}
The possibility of electrifying the transport sector in Crete, Greece has been investigated. Currently the conventional vehicles in Crete consume annually 316,872 tons of gasoline and diesel oil emitting $1,030,188$ tons of $\mathrm{CO}_{2}$. Electrification of the transport sector in Crete will result in a decrease of imported fossil fuels use and a reduction of $\mathrm{CO}_{2}$ emissions. It will also increase the use of locally available renewable energies in electricity generation. If all the existing conventional vehicles in Crete were to be replaced by electric vehicles, the annual electricity requirements in their batteries would be $1,092,568$ to $1,311,077 \mathrm{MWh}$ depending on the type of battery. The energy demand of the electric cars could be covered with electricity generated by renewable energies including solar and wind energy which are abundant in the island. The batteries of the electric cars could be used as electricity storage devices facilitating the penetration of intermittent renewable energies, with distributed generation systems, into the smart electric grid of Crete. It has been estimated that the aggregated theoretical storage capacity of all the batteries would be 6.33 GWh and that the size of the solar-PV plants and wind energy systems, generating all the electricity required by electric vehicles, would be 728 to 874 MWp and 445 to $534 \mathrm{MW}$ respectively.
\end{abstract}

\section{Keywords}

Battery, Carbon Emissions, Crete, Electric Vehicles, Renewable Energies

\section{Introduction}

Worldwide the transport sector is mainly powered with fossil fuels although various types of electric vehicles (EVs) including battery electric vehicles (BEVs), hybrid electric vehicles (HEVs) and fuel cell vehicles (FCVs) are slowly replacing conventional vehicles. Electrification of the transport sector has many advantag- 
es compared with conventional transportation including, a) reduction of the use of fossil fuels imported in many countries, b) reduction of carbon emissions due to fossil fuels use, and c) improvement of air quality mainly in large cities. The use of alternative energy sources for electricity generation required in BEVs could reduce or eliminate the use of fossil fuels in transportation and constitutes a compelling challenge in our societies. The development of distributed power generation systems using renewable energy sources and smart electric grids combined with the possibility of using the batteries of EVs as electricity storage devices could take off the electrification of the transport sector in the future.

\subsection{Fuel Consumption and Carbon Emissions in Vehicles}

A report concerning energy consumption and $\mathrm{CO}_{2}$ emissions of various BEVs has been published by the European association for battery electric vehicles, 2009 [1]. According to this report BEVs, excluding HEVs, consume less primary energy and significantly less final energy than internal combustion engine vehicles (ICEVs) of the same size and performance. Regarding carbon emissions, ICEVs emit 1.9 - 2.4 more $\mathrm{CO}_{2}$ than BEVs. A study on fuel consumption and $\mathrm{CO}_{2}$ emissions from passenger cars in Europe has been published by Fontaras et al., 2017 [2]. The authors found a progressive decline over time in the average fuel consumption and $\mathrm{CO}_{2}$ emissions of the European passenger car fleet. They also stated that real life fuel consumption is $30 \%-40 \%$ higher than officially reported by the manufacturers. Factors explaining this large difference include driving behavior, vehicle configuration, air condition use, and traffic conditions. Additional rather neglected factors include side winds, rain, snow, and road grade. The authors also stated that in all published studies the gap between the manufacturer's indicative fuel consumption and real life consumption is increasing with time. Real world fuel consumption of passenger cars has been reported by Ligterink et al., 2014 [3]. The authors found a difference between official and actual fuel consumption. They stated that the difference is increasing with time and the gap between the two values is remarkable. Thomas, 2009 [4] compared various types of vehicles to find the best options for mitigating climate change, lowering air pollution and reducing the dependency on imported oil. The author developed a computer simulation model to assess various types of vehicles. He concluded that the use of BEVs combined with the use of hybrid vehicles and vehicles using biofuels could reduce $\mathrm{CO}_{2}$ emissions by $80 \%$ compared to 1990s levels. He also stated that between BEVs and FCVs, fuel cells are superior to batteries for ranges above $160 \mathrm{Km}$.

\subsection{Electric Vehicles}

The economics of EVs have been presented by Newbery, 2013 [5]. The author compared BEVs with ICEVs. He stated that BEV economics depend on costs of battery, carbon and road fuels and the cost of electricity at the charging points. He concluded that economics of BEVs look doubtful even by 2020 without sub- 
sidies or much higher carbon and oil prices. A study on technologies for electric, hybrid and hydrogen vehicles has been published by Jorgensen, 2008 [6]. The author investigated various aspects including energy utilization, vehicle range, costs and durability of batteries for the above-mentioned types of vehicles. $\mathrm{He}$ concluded that it was difficult to identify which type of vehicle was the best taking into account the various uncertainties among their different types. Measurement of power loss during EV charging and recharging has been investigated by Apostolaki-Iosifidou et al., 2017 [7]. The authors reported that according to their measurements, losses vary from $12 \%$ to $36 \%$. Predominant losses occur in the power electronics used for alternative current to direct current conversion. The authors also stated that electronics efficiency is lowest at lower power transfer and in a low state of charge while it is lower during discharging than charging. A comparative environmental life cycle assessment of conventional vehicles and EVs has been presented by Hawkins et al., 2012 [8]. The authors reported that assuming a vehicle lifetime of $200,000 \mathrm{~km}$, the global warming potential of EVs is $27 \%$ to $29 \%$ better compared with gasoline vehicles and $17 \%$ to $20 \%$ better compared with diesel vehicles. However, they stated, their results are sensitive regarding the electricity source, vehicle life time and the frequency of battery replacement. A cost comparison of fuel cell vehicle FCVs and BEVs has been published by Eaves et al., 2004 [9]. The authors have compared the manufacturing and refueling costs of a BEV and a FCV delivering 135 $\mathrm{hp}$ and driving approximately 300 miles. Their results indicated that a BEV performs much more favorably in terms of cost, energy efficiency, weight and volume. The differences are much higher in the case where energy is derived from renewable resources. In this case the FCV requires production of 2.5 times more energy than a comparable BEV. Wu et al., 2012 [10] have investigated the energy consumption and $\mathrm{CO}_{2}$ emissions impact of vehicle electrification in three developed regions in China. The authors stated that promotion of EVs would reduce oil use significantly but mitigation of $\mathrm{CO}_{2}$ emissions is more difficult than oil use reduction. They considered that vehicle electrification consists of an industrial revolution promoting sustainable transportation in China. The role of plug-in electric vehicles combined with the use of renewable energies in electricity systems has been studied by Weiller et al., 2016 [11]. The authors stated that two technology options, renewable energy generation and electrification of transportation, could assist in the achievement of two important goals in our societies, to cover the energy demand and to reduce carbon emissions. The deployment of renewable energies and BEVs combined with the operation of smart electric grids creates many synergies improving the overall energy sustainability. At the scale of individual households, ownership of BEVs provides advantages and synergies for end-users who also own rooftop solar-PV panels. A study on the cost-effectiveness of electric vehicle battery capacity and charging infrastructure investment has been implemented by Peterson et al., 2013 [12]. The authors analyzed the current United States policy regarding subsidies for buying EVs and subsidies for installing charging stations. They found that the least cost 
solution is the option of low capacity plug-in electric vehicles or gasoline-powered hybrid electric vehicles.

\subsection{Integration of Electric Vehicles in Smart Grids with Renewable Energies}

The integration of electric vehicles and renewable energy sources in the electric grid has been investigated by Richardson, 2013 [13]. The author has indicated that the adoption of electric vehicles has positive impacts in the integration of renewable energies into the existing electric grids. Therefore EVs can reduce carbon emissions from the transport sector and, additionally, reduce electricity generation from fossil fuels. Smart electricity grids allow EVs to be used as distributed storage mechanism for absorbing excess renewable energy electricity at off-peak times when it is otherwise unwanted. Creation of smart energy systems for $100 \%$ renewable energy for transport solutions has been presented by Mathiesen et al., 2015 [14]. The authors have proposed the integration of the electricity sector with the heating and transport sector combined with energy storage technologies. The integrated energy systems could utilize only renewable energies combining various sustainable energy technologies in order to provide heating, electricity and transport in a community. A review of energy sources and energy management systems in electric vehicles has been presented by Tie et al., 2013 [15]. The authors stated that increasing use of BEVs would increase demand for grid electricity. This will allow higher use of intermittent renewable energies for grid electricity generation. Smart grid control will permit better management of the demand assisting the integration of the transport sector with the grid utility sector. Integrated transport and renewable energy systems have been investigated by Mathiesen et al., 2008 [16]. The authors stated that the conversion of the transport sector to $100 \%$ renewable is possible but it is connected with many challenges. Among them is the higher use of intermittent renewable energy sources in the transport, electricity and heating sector. With reference to the Danish case, the authors concluded that $100 \%$ renewable energy transport is achievable with moderate use of biofuels combined with various renewable energy and hydrogen technologies. Integration of private transport into renewable energy policy has been investigated by Andersen et al., 2009 [17]. The authors proposed the creation of an electric recharge grid operator of an intelligent rechargeable network for vehicles. The new business model could solve two important problems. The first includes the use of the electric grid with a substantial increase of renewable electricity generation for charging electric vehicles. The second concerns the reduction of carbon emissions from the transport sector. The authors concluded that this model also transforms BEVs into distributing storage devices for electricity. Tomic et al., 2007 [18] investigated the use of BEV fleets for grid support regulating the electricity markets. The authors studied the use of EVs for the regulation of four US regional electricity markets stating that results depend upon the market value of regulating services, the power capacity of the electrical connections and the storage capacity of the ve- 
hicle's batteries. They concluded that vehicle-to-grid power could provide an economic benefit improving the economics of grid-connected EVs. It would also improve the stability of the electric grid. Mwasilu et al., 2014 [19] have reported on interaction of BEVs with smart grids and the interaction of renewable energies with them. The authors concluded that EVs can provide ancillary services to the grid such as voltage and frequency regulation, peak power leveraging support and reduction of the power system operating cost. The interaction of BEVs with the electric grid would increase the penetration of intermittent renewable energies including solar photovoltaic (solar-PV) and wind energy into the electrical system. Short et al., 2006 [20] assessed the synergies between plug-in electric vehicles and wind energy electricity. The authors stated that the use of the above-mentioned vehicles could increase the penetration of wind energy into the electric grid. Higher storage capacity in the car's batteries would allow higher generation of grid electricity from wind mills. A study on the use of BEVs as dispersed energy storage systems in smart grids has been published by Pang et al., 2012 [21]. The authors stated that the peak load shifting strategy using BEVs could reduce on-peak load demand and energy consumption which in turn reduces the electricity purchase cost for the customer and the vehicle owner. They also suggested that with enough available BEVs their aggregated batteries could be used to support the electricity demand of a building and create revenue for the vehicle owner. Dallinger et al., 2012 [22] have investigated the grid integration of intermittent renewable energy sources using batteries of EVs for storing electricity. The authors reported that the use of BEVs could balance the fluctuation of renewable energies smoothing the peak loads in the grid. They concluded that the use of BEVs for electricity storage could improve the integration of intermittent renewable energies in smart electric grids. Helms et al., 2010 [23] have reported on life cycle emissions of BEVs and plug-in HEVs. The authors have stated that EVs charged with additional renewable energies lead to a significant improvement in the greenhouse gas balance, whereas other electricity sources lead to no substantial improvement or even higher life cycle emissions. Therefore, they concluded, from an environmental point of view it is necessary that the market penetration of EVs should be based on the additional use of renewable energy sources.

Objectives of the current work include:

Estimation of the fossil fuels currently used in transportation in Crete, Greece,

Estimation of the energy efficiencies in various types of ICEVs and in BEVs,

Estimation of the electricity required for powering BEVs in Crete, Greece replacing all the existing ICEVs in the island,

Estimation of the capacity of various renewable energy installations, mainly solar-PV and wind energy systems, which could provide all the required electricity in the transport sector in Crete, and

Assessment of the environmental and economic benefits from the electrification of the transport sector in Crete, Greece. 


\section{Use of Conventional Fuels in Vehicles in Crete}

Currently the majority of vehicles in Crete consume conventional fuels including gasoline and diesel oil. Very few vehicles use gas fuels and the number of BEVs and FCVs in the island is very limited. The current number of various types of vehicles and motorcycles in Crete is presented in Table 1.

The population of Crete has been reported at 682,928 inhabitants and the electricity demand at $2837.8 \mathrm{GWh}$, Alexakis, 2014 [25]. The annual consumption of gasoline and diesel oil in transport in Crete is presented in Table 2.

Assuming that emissions in electricity generation, for the energy mix of Crete, are 0.75 tons $\mathrm{CO}_{2}$ per $\mathrm{MWh}$, the total annual $\mathrm{CO}_{2}$ emissions in Crete due to electricity demand are $2,128,350$ tons or 3.12 tons per capita.

\section{Energy Efficiencies in ICEVs and in BEVs}

Energy efficiency in ICEVs and BEVs depend on various parameters including:

The efficiency during the production, refining and transport of fuel,

The efficiency from the tank to the wheels for ICEVs,

The efficiency of power generation from conventional fuels, and

The efficiency from the plug to the wheels for BEVs.

Energy efficiencies for BEVs in various stages of energy transmission for two different types of batteries are presented in Table 3. Comparison of energy efficiency of various types of vehicles with ICEs and batteries are presented in Figure 1. It should be noted that the efficiencies reported are under ideal conditions. Real-life efficiencies depend on various factors and they could be $30 \%$ $40 \%$ lower than those reported in the tables.

Table 3 indicates that BEVs with lithium-ion batteries have better efficiencies than BEVs with lead-acid batteries. Figure 1 indicates that BEVs have better overall energy efficiencies than ICEVs. If though the electricity used in batteries of EVs is generated by renewable energies instead of fossil fuels the general picture is quite different and more favorable to BEVs.

The primary energy source content of gasoline and diesel oil used annually in ICEVs in Crete, Greece is presented in Figure 2.

\section{Annual Electricity Requirements in BEVs Replacing All the ICEVs in Crete, Greece}

Electricity requirements in the case where all the ICEVs are replaced by BEVs in Crete has been estimated as well as the primary energy source required if grid

Table 1. Current number of ICEVs and motorcycles in Crete (2016) ${ }^{1}$.

\begin{tabular}{cc}
\hline Type of vehicle & Number \\
\hline Passenger cars & 263,517 \\
Trucks & 129,294 \\
Buses & 1,177 \\
Motorcycles & 137,759
\end{tabular}

${ }^{1}$ Source: http://www.statistics.gr/ [24]. 
Table 2. Annual consumption of conventional transport fuels in Crete (2016).

\begin{tabular}{ccccc}
\hline Transport fuel & $\begin{array}{c}\text { Annual } \\
\text { consumption } \\
\text { (tons) }\end{array}$ & $\begin{array}{c}\text { Energy content } \\
(\mathrm{MWh} \text { per } \\
\text { year })^{2,3}\end{array}$ & $\begin{array}{c}\mathrm{CO}_{2} \text { emissions } \\
\text { (tons } \mathrm{CO}_{2} \text { per } \\
\text { year })^{4,5}\end{array}$ & $\begin{array}{c}\mathrm{CO}_{2} \text { emissions } \\
\text { (tons } \mathrm{CO}_{2} \text { per } \\
\text { capita per year) }\end{array}$ \\
\hline Gasoline & 161,968 & $2,081,289$ & 534,495 & 0.783 \\
Diesel oil & 154,904 & $1,872,789$ & 495,693 & 0.726 \\
Total & 316,872 & $3,954,078$ & $1,030,188$ & 1.509 \\
\hline
\end{tabular}

${ }^{1}$ Source: http://www.statistics.gr/ [24]; ${ }^{2}$ Energy content of gasoline $=12.85 \mathrm{KWh}$ per kg; ${ }^{3}$ Energy content of diesel oil $=12.09 \mathrm{KWh}$ per kg; ${ }^{4} \mathrm{CO}_{2}$ emissions from gasoline $=3.3 \mathrm{kgCO}_{2}$ per kg; ${ }^{5} \mathrm{CO}_{2}$ emissions from diesel oil $=3.2 \mathrm{kgCO}_{2}$ per kg.

Table 3. Energy efficiency of BEVs from the electric plug to the wheel ${ }^{1,2}$.

\begin{tabular}{ccc}
\hline Stage of energy transmission & BEVs with lead-acid batteries & BEVs with lithium-ion batteries \\
\hline Charger & $85 \%-87 \%$ & $88 \%-90 \%$ \\
Charging and discharging cycle & $75 \%-85 \%$ & $85 \%-95 \%$ \\
Electronic management & $96 \%-98 \%$ & $96 \%-98 \%$ \\
Electric motor & $90 \%-95 \%$ & $90 \%-95 \%$ \\
Total & $55 \%-65 \%$ & $65 \%-79 \%$ \\
Total average & $60 \%$ & $72 \%$ \\
\hline
\end{tabular}

${ }^{1}$ Source: European association for battery electric vehicles, $2009 ;{ }^{2}$ Values are estimated for ideal conditions. Efficiencies in real-life conditions are lower.

\section{Total energy efficiency of various vehicles (\%)}

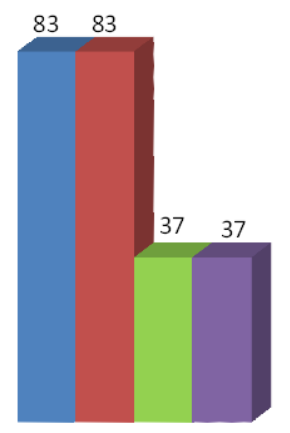

From the primary energy source to the tank/plug

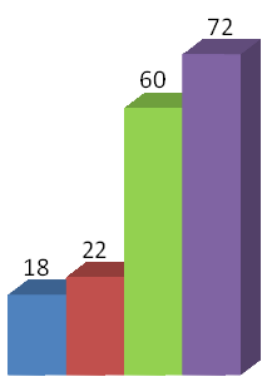

From the tank/plug to the wheel

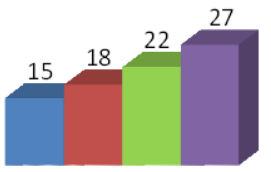

From primary energy source to the wheel

\section{- ICEVs-Gasoline}

- ICEVs-Diesel

BEVs with lead-acid batteries

BEVs with lithium-ion batteries

Figure 1. Total energy efficiency of various vehicles ${ }^{1,2,3} .{ }^{1}$ Source: European association for battery electric vehicles, 2009; ${ }^{2}$ Values are estimated for ideal conditions. Efficiencies in real-life conditions are lower; ${ }^{3}$ Assuming that the electricity used for battery charging is generated by oil.

electricity, generated by oil, is used for battery charging. The results are presented in Figure 3. 


\section{Energy use in convential vehicles in Crete, Greece in 2016 (MWh/year)}

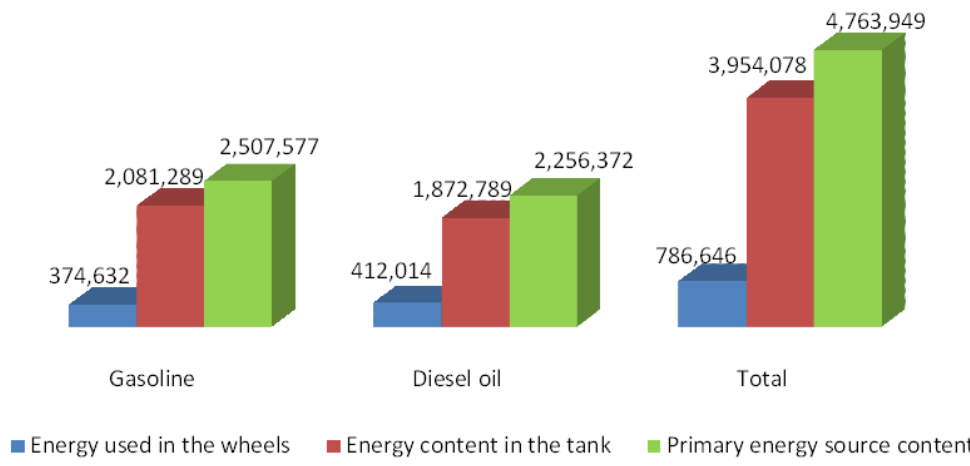

Figure 2. Wheel energy use and primary energy source content of gasoline and diesel oil used annually in ICEVs in Crete, Greece $(2016)^{1}$. ${ }^{1}$ Efficiency, primary energy source to the fuel $=0.83$.

\section{Electricity requirements in BEVs replacing all the ICEVs in Crete, Greece in 2016 (MWh/year)}

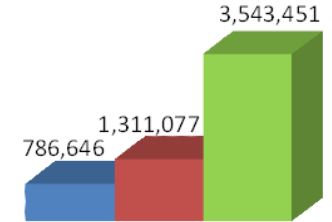

BEVs with lead-acid batteries

Electricity used in the wheels

Primary energy source content

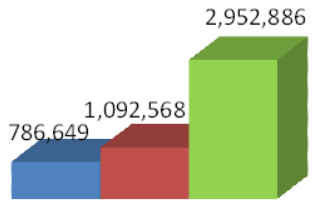

BEVs with lithium-ion batteries

Electricity required in the batteries

Figure 3. Electricity requirements in BEVs replacing all the ICEVs in Crete, Greece $(2016)^{1} .{ }^{1}$ In the case where oil is used for electricity generation with 0.37 efficiency.

Comparing Figure 2 and Figure 3 it is shown that the primary energy source requirements are significantly lower in the case of BEVs than in the case of ICEVs. The annual electricity requirements by BEVs in Crete are less than half the current electricity demand in the island (2,837,800 MWh). The storage capacity of the batteries in the vehicle fleet in Crete would be high. Assuming that all the current 263,517 passenger cars in Crete had electric batteries with an average size of $30 \mathrm{KWh}$ each and a maximum depth of discharge of $80 \%$, then their total theoretical storage capacity would be $6.33 \mathrm{GWh}$ which corresponds to $0.22 \%$ of the current annual electricity consumption in the island. Electricity storage in electric vehicles' batteries combined with water pumping storage systems could facilitate the higher penetration of intermittent renewable energies in the electric grid in Crete. However frequent charging and discharging of the 
electric batteries could result in their fast deterioration. This fact should be taken into account if they are going to be used for electricity storage.

\section{Estimation of the Size of Renewable Energy Installations Generating the Required Electricity for Powering All the BEVs in Crete, Greece}

Replacement of all the current operating ICEVs with BEVs in Crete would significantly increase the current demand of electricity. However due to high wind velocities and abundant solar irradiance in the island, renewable energies could be used for electricity generation in order to supply part or all of the additional electricity required by the BEVs. This could be obtained with various distributed solar-PV and wind power installations regulated with a smart grid control system. The electric grid in Crete is not interconnected with the continental grid of Greece and the existing solar-PV and wind energy installations in the island provide up to $20 \%$ of its annual electricity demand. Hydro-power and geothermal energy resources in Crete are limited and the existing biomass resources are mainly used for heat generation. Annual electricity requirements in Crete with or without the operation of BEVs are presented in Figure 4.

\subsection{Solar Photovoltaic Installations}

Solar-PV systems could be used for the generation of the electricity required for the operation of BEVs in Crete. Estimation of the nominal power of the solar-PV systems is made assuming that $1 \mathrm{KWp}$ generates $1500 \mathrm{KWh}$ annually in Crete.

\subsection{Wind Power Installations}

Wind power systems could also be used for generation of the required electricity. Average wind velocities in many areas in Crete are very high and the estimation of the power of wind mills is made assuming that their capacity factor is 0.28 . Therefore a wind mill of $1 \mathrm{KW}$ will generate $2453 \mathrm{KWh}$ annually in Crete. The size of the solar-PV and the wind power systems for providing all the required electricity for the operation of BEVs in Crete is presented in Table 4.

Assuming that in real-life BEV driving conditions, the required electricity will be higher than in ideal driving conditions, it is concluded that the size of the solar-PV and wind power installations will be higher than the values reported in Table 4.

\section{Environmental and Economic Impacts from the Replacement of All the ICEVs with BEVs in Crete}

Electrification of the transport sector in Crete, Greece, provided that the required electricity will be generated by renewable energies, will have positive environmental impacts including reduction of carbon emissions, improvement of air quality and lower use of fossil fuels. Assuming that all the ICEVs in Crete were to be replaced by BEVs fuelled by electricity generated by renewable 


\section{Annual electricity requirements in Crete with or without the operation of BEVs (MWh)}

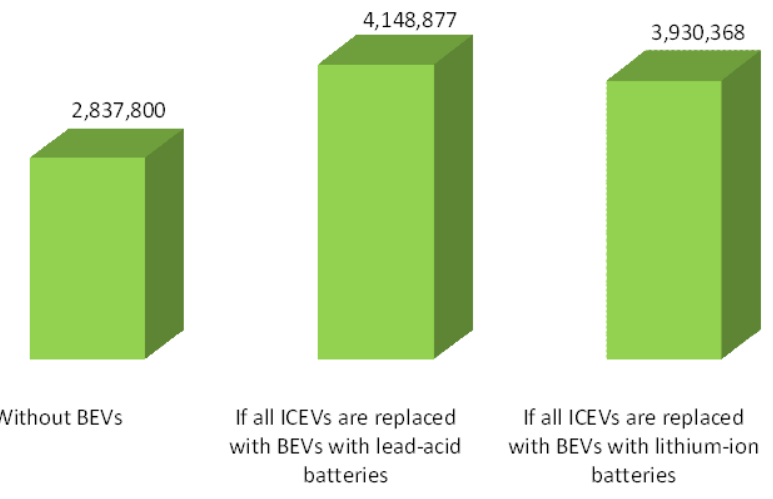

Figure 4. Annual electricity requirements in Crete with or without the operation of BEVs.

Table 4. Size of the solar-PV and wind power systems in order to provide all the required electricity for the operation of the BEVs in Crete.

\begin{tabular}{lccc}
\hline Type of battery in BEV & $\begin{array}{c}\text { Annual electricity } \\
\text { requirements } \\
\text { (MWh) }\end{array}$ & $\begin{array}{c}\text { Size of solar-PV } \\
\text { systems to provide the } \\
\text { electricity needed } \\
\text { (MWp) }\end{array}$ & $\begin{array}{c}\text { Size of wind power } \\
\text { systems to provide the } \\
\text { electricity needed } \\
\text { (MW) }\end{array}$ \\
\hline $\begin{array}{c}\text { Operation of BEVs with } \\
\text { lead-acid batteries }\end{array}$ & $1,311,077$ & 874 & 534 \\
$\begin{array}{c}\text { Operation of BEVs with } \\
\text { lithium-ion batteries }\end{array}$ & $1,092,568$ & 728 & 445 \\
\hline
\end{tabular}

energies, the reduction of $\mathrm{CO}_{2}$ emissions in the transport sector in the island would be, according to Table 2, 1,030,188 tons $\mathrm{CO}_{2}$ per year or 1.509 tons $\mathrm{CO}_{2}$ per capita per year. The cost of the required solar-PV plants and wind mills for generating all the electricity consumed by BEVs under ideal driving conditions in Crete are presented in Figure 5. The implementation of new investments in renewable energy installations for electricity generation is also a desired impact related with the electrification of the transport sector in Crete.

\section{Discussion}

The availability of renewable energy sources, particularly solar and wind energy, in the island of Crete, Greece is high. Currently they are used for electricity generation covering annually up to $20 \%$ of the total electricity demand in the island. However they could also be used in the future for powering EVs. The main fuels used in transportation in Crete are gasoline and diesel oil since the majority of the existing vehicles are ICEVs. Since oil is imported in Greece the possibility of using EVs instead of ICEVs in Crete powered by local indigenous energy sources is challenging. The energy content of the transport fuels used in the island is 


\section{Capital cost of solar and wind power systems generating all the required electricity for the operation of BEVs in Crete under ideal driving conditions (mil $€$ )}

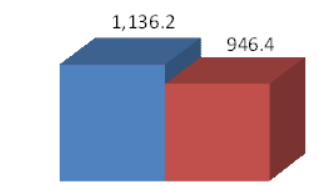

Capital cost of solar-PV plants n BEVs with lead-acid batteries

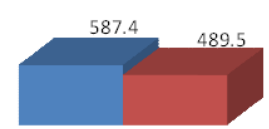

Capital cost of wind mills

Figure 5. Capital cost of solar and wind power systems generating all the required electricity for the operation of BEVs in Crete under ideal driving conditions ${ }^{1,2}$. ${ }^{1}$ Capital cost of solar-PV plants $=1300 €$ per $\mathrm{KWp} ;{ }^{2}$ Capital cost of wind mills $=1100 €$ per KW.

high and it is comparable with its total annual electricity demand. Since solar and wind energy, which are currently used for electricity generation in the island, are intermittent energy sources, they are not utilized in an optimum way in the grid. Replacement of ICEVs with EVs in Crete should be combined with increased use of distributed electricity generation systems, mainly using solar and wind power, and the smart operation of the electric grid. Electricity storage in vehicles' batteries could result in smoothing the peak electricity loads, improving the grid performance. The aggregate storage capacity of the batteries in the available EVs could be high. Batteries could be charged from the grid at peak-off loads with low cost and discharged to the grid at peak-on loads with higher cost. Therefore owners of BEVs could obtain an additional income using their batteries as a grid storage mechanism. This could be combined with the installation of solar photovoltaic panels on the terraces of buildings generating grid electricity and offering economic benefits to their owners. Smoothing the peak grid loads would increase the penetration of intermittent renewable energy sources in electricity generation with distributed generation systems in Crete. However the frequent charging and de-charging of the batteries could deteriorate their quality, decreasing their life time, and a cost-benefit analysis must be done to quantify this effect. Promotion of electrification in the transport sector in Crete requires the cooperation of the public sector the private investors and the consumers. Since the current prices of EVs are high compared with the prices of conventional vehicles their adoption needs some kind of direct or indirect subsidies from the state. However the current deep economic and monetary crisis in Greece does not allow that. The decrease of the citizen's income due to the crisis does not also allow their higher spending for buying EVs. Increase of electric transportation in Crete requires the creation of the necessary infrastructure in battery charging stations which does not exist at the moment. Creation of additional solar-PV plants and wind power stations are necessary for generating the excess electricity needed for charging batteries. However the fact that the electric grid in Crete is not interconnected with the grid of continental Greece limits the 
creation of new installations of intermittent renewable energy sources in Crete like solar-PV and wind power. The problems regarding electrification of the transport sector in Crete with the use of renewable energies are both technical and financial. Technical due to the limitations of the existing electric grid and financial due to the lack of financial resources in the state, in the banks and in consumers. Therefore there are many barriers and challenges which must be overcome in order to promote broad electrification of the transport sector in Crete.

\section{Conclusions}

The main conclusions of the current work are:

1) The existing vehicles in Crete are equipped with ICEs and they consume annually 161,968 tons of gasoline and 154,904 tons of diesel oil. The number of EVs in Crete is currently very limited. The total annual $\mathrm{CO}_{2}$ emissions in Crete due to the use of transport fuel are $1,030,188$ tons $\mathrm{CO}_{2}$ or 1.509 tons $\mathrm{CO}_{2}$ per capita. These emissions are approximately half the corresponding $\mathrm{CO}_{2}$ emissions during electricity generation in the island.

2) Electrification of the transport sector in Crete will result in the decrease of fossil fuels used and the subsequent carbon emissions. It will also result in the increase of indigenous renewable energies use, particularly solar and wind energy, which are abundant in the island, for electricity generation.

3) If all ICEVs in Crete were replaced with BEVs, their annual electricity requirements would be 1,092,568 MWh if lithium-ion batteries are used and 1,311,077 MWh if lead-acid batteries are used. The annual energy requirements in all BEVs are approximately half the current electricity demand in the island.

4) The batteries of the EVs could be used as electricity storage mechanisms, additionally to water pumping stations, smoothing the peak-on and peak-off loads of the grid and facilitating the penetration of intermittent renewable energy sources into it. The aggregated theoretical storage capacity of all the BEVs in Crete, replacing the existing ICEVs, has been estimated at $6.33 \mathrm{GWh}$, corresponding to $0.22 \%$ of the total electricity demand in the island.

5) The size of the solar-PV plants which could generate all the required electricity in all the BEVs in Crete has been estimated at $874 \mathrm{MWp}$ if the BEVs use lead-acid batteries and at $728 \mathrm{MWp}$ if they use lithium-ion batteries. Their capital cost has been estimated at $€ 1136.2$ mil. and $€ 946.4$ mil. respectively.

6) The size of the wind power systems which could generate all the required electricity in all the BEVs in Crete has been estimated at $534 \mathrm{MWp}$ if the BEVs use lead-acid batteries, and $445 \mathrm{MWp}$ if they use lithium-ion batteries. Their capital cost has been estimated at $€ 587.4 \mathrm{mil}$. and $€ 489.5$ mil. respectively.

Further research work should investigate the possibility of the combined use of BEVs together with HEVs, FCVs and ICEVs using bio-fuels for zeroing carbon emissions in the transport sector in Crete. It should also investigate, with simulation techniques, the possibility of smoothing the peak-on and peak-off 
electric loads in the grid using electricity generated by intermittent renewable energy sources and stored in the batteries of the EVs.

\section{Acknowledgements}

The author thanks Mr. George Angelakis for his assistance in the preparation of the figures in the text.

\section{References}

[1] European Association for Battery Electric Vehicles (2009) Energy Consumption, $\mathrm{CO}_{2}$ Emissions and Other Considerations Related to Battery Electric Vehicles. https://ec.europa.eu/transport/sites/transport/files/themes/strategies/consultations/ doc/2009_03_27_future_of_transport/20090408_eabev_\%28scientific_study\%29.pdf

[2] Fontaras, G., Zacharof, N.G. and Giuffo, B. (2017) Fuel Consumption and $\mathrm{CO}_{2}$ Emissions from Passengers Cars in Europe-Laboratory versus Real-World Emissions. Progress in Energy and Combustion Science, 60, 97-131. https://doi.org/10.1016/j.pecs.2016.12.004

[3] Ligterink, N.E. and Eijk, A.R.A. (2014) Real-World Fuel Consumption of Passengers Cars. Sustainable Transport and Logistics Group, TNO, Delft.

[4] Thomas, C.E. (2009) Fuel Cell and Battery Electric Vehicles Compared. International Journal of Hydrogen Energy, 34, 6005-6020. https://doi.org/10.1016/j.ijhydene.2009.06.003

[5] Newbery, D. (2013) The Economics of Electric Vehicles. Electricity Policy and Research Group, Seminar at Cambridge, Cambridge, 21 January 2013.

http://www.eprg.group.cam.ac.uk/wp-content/uploads/2013/01/EEJan13_Economic sEVs.pdf

[6] Jorgensen, K. (2008) Technologies for Electric, Hybrid and Hydrogen Vehicles: Electricity from Renewable Energy Sources in Transport. Utilities Policy, 16, 72-79. https://doi.org/10.1016/j.jup.2007.11.005

[7] Apostolaki-Iosifidou, E., Codani, P. and Kempton, W. (2017) Measurement of Power Loss during Electric Vehicle Charging and Recharging. Energy, 127, 730-742. https://doi.org/10.1016/j.energy.2017.03.015

[8] Hawkins, T.R., Singh, B. Majeau-Bettez, G. and Stromman, A.H. (2012) Comparative Environmental Life Cycle Assessment of Conventional and Electric Vehicles. Journal of Industrial Ecology, 17, 53-64. https://doi.org/10.1111/j.1530-9290.2012.00532.x

[9] Eaves, S. and Eaves, J. (2004) A Cost Comparison of Fuel Cell and Battery Electric Vehicles. Journal of Power Sources, 130, 208-212. https://doi.org/10.1016/j.jpowsour.2003.12.016

[10] Wu, Y., Yang, Z., Lin, B., Liu, H., Wang, R., Zhou, B. and Hao, J. (2012) Energy Consumption and $\mathrm{CO}_{2}$ Emission Impacts of Vehicle Electrification in Three Developed Regions in China. Energy Policy, 48, 537-550. https://doi.org/10.1016/j.enpol.2012.05.060

[11] Weiller, C. and Sioshansi, R. (2016) The Role of Plug-In Electric Vehicles with Renewable Resources in Electricity Systems. Revue d'Economie Industrialle, 148, 291-316. http://journals.openedition.org/rei/6008

[12] Peterson, S.B. and Michalek, J.J. (2013) Cost-Effectiveness of Plug-In Hybrid Electric Vehicle Battery Capacity and Charging Infrastructure Investment for Reducing US Gasoline Consumption. Energy Policy, 52, 429-438. 
https://doi.org/10.1016/j.enpol.2012.09.059

[13] Richardson, D.B. (2013) Electric Vehicles and Electric Grid: A Review of Modeling Approaches, Impacts and Renewable Energy Integration. Renewable and Sustainable Energy Reviews, 19, 247-254. https://doi.org/10.1016/j.rser.2012.11.042

[14] Mathiesen, B.V., Lund, H. and Norgaard, P. (2008) Integrated Transport and Renewable Energy Systems. Utilities Policy, 16, 107-116. https://doi.org/10.1016/j.jup.2007.11.007

[15] Tie, S.F. and Tan, C.W. (2013) A Review of Energy Sources and Energy Management System in Electric Vehicles. Renewable and Sustainable Energy Reviews, 20, 82-102. https://doi.org/10.1016/j.rser.2012.11.077

[16] Mathiesen, B.V., Lund, H., Conolly, D., Wenzel, H., Ostergaard, P.A., Moller, B., Nielsen, S., Ridzan, I., Karnoe, P., Sperling, K. and Hvelplund, F.K. (2015) Smart Energy Systems for Coherent 100\% Renewable Energy and Transport Solutions. Applied Energy, 145, 139-154. https://doi.org/10.1016/j.apenergy.2015.01.075

[17] Andersen, P.H., Mathews, J.A. and Rask, M. (2009) Integrated Private Transport into Renewable Energy Policy: The Strategy of Creating Intelligent Recharging Grids for Electric Vehicles. Energy Policy, 37, 2481-2486.

https://doi.org/10.1016/j.enpol.2009.03.032

[18] Tomic, J. and Kempton, W. (2007) Using Fleets of Electric-Drive Vehicles for Grid Support. Journal of Power Sources, 168, 459-468.

https://doi.org/10.1016/j.jpowsour.2007.03.010

[19] Mwasilu, F., Justo, J.J., Kim, E.K., Do, T.D. and Jung, J.W. (2014) Electric Vehicles and Smart Grid Interaction: A Review on Vehicle to Grid and Renewable Energy Sources Integration. Renewable and Sustainable Energy Reviews, 34, 501-516. https://doi.org/10.1016/j.rser.2014.03.031

[20] Short, W. and Denholm, P. (2006) A Preliminary Assessment of Plug-In Hybrid Electric Vehicles on Wind Energy Markets. Technical Report NREL/TP-620-39729, National Renewable Energy Laboratory, US Department of Energy.

[21] Pang, C., Dutta, P. and Kezunovic, M. (2012) BEVs/PHEVs as Dispersed Energy Storage for V2B Uses in the Smart Grid. IEEE Transactions on Smart Grid, 3, 473-482. https://doi.org/10.1109/TSG.2011.2172228

[22] Dallinger, D. and Wietschel, M. (2012) Grid Integration of Intermittent Renewable Energy Sources Using Price-Responsive Plug-In Electric Vehicles. Renewable and Sustainable Energy Reviews, 16, 3370-3382.

https://doi.org/10.1016/j.rser.2012.02.019

[23] Helms, H., Pehnt, M., Lambrecht, U. and Liebich, A. (2010) Electric Vehicle and Plug-In Hybrid Energy Efficiency and Life Cycle Emissions. Proceedings of 18 th International Symposium Transport and Air Pollution, Dübendorf, 18-19 May 2010, 113-124.

[24] http://www.statistics.gr

[25] Alexakis, G. (2014) The Region of Crete and the EU's 2030 Energy and Climate Goals. 42 th General Assembly of CPMR, Umea, 24-26 September 2014.

http://www.crpm.org/pub/agenda/2677_ag_2014_session_6_ppt_alexakis.pdf 